Bojan Krstić ${ }^{1}$

University of Niš, Faculty of Economics

Jelena Petrović ${ }^{2}$

University of Niš, Faculty of Science and Mathematics

Tanja Stanišić ${ }^{3}$

University of Kragujevac, Faculty of Hotel Management and

Tourism in Vrnjačka Banja, Researcher on the project No. 179066
SCIENTIFIC REVIEW ARTICLE doi:10.5937/ekonomika1503061K

Received: June 26, 2015

Accepted: August 31, 2015

\title{
ANALYSIS OF KEY INDICATORS OF ECONOMIC DIMENSIONS OF SPAS' SUSTAINABLE DEVELOPMENT IN SERBIA AS TOURISM DESTINATIONS ${ }^{4}$
}

\begin{abstract}
The purpose of this paper is to analyse the economic indicators of sustainable development of spas in Serbia. The paper starts from the newest division of sustainable development indicators of the tourist destination given by the European Commission. The aim is the ranking of the leading spas in Serbia according to the level of tourism economic sustainability. The following methods are used in the paper: VIKOR method for determining the level of economic sustainability of tourist destination development, and FANMA method for determining the weight coefficients which are necessary for the implementation of VIKOR methods. Based on VIKOR method and starting from the economic indicators of sustainability of the tourist destinations, the leading spas in Serbia are ranked according to the economic sustainability of their development as tourist destinations. The research results indicate to tourism development policy makers to which the spas in Serbia activities should be directed in order to increase the level of their economic sustainable development.
\end{abstract}

Key words: tourist destination, development, spas, economic indicators, sustainability

JEL classification: 0290

\footnotetext{
${ }^{1}$ bojan.krstic@eknfak.ni.ac.rs

2 jelenapetrovic619@yahoo.com

3 tanja.stanisic@gmail.com

${ }^{4}$ Paper is a part of research within the project No. 179066 - Improving the competitiveness of the public and private sector by networking competences in the process of the European integrations of Serbia, financed by the Ministry of Education, Science and Technological Development of the Republic of Serbia.
} 


\title{
АНАЛИЗА КЉУЧНИХ ИНДИКАТОРА ЕКОНОМСКЕ ДИМЕНЗИЈЕ ОДРЖИВОГ РАЗВОЈА БАЊА У СРБИЈИ КАО ТУРИСТИЧКИХ ДЕСТИНАЦИЈА
}

\begin{abstract}
Апстракт
Сврха овог рада је анализа економских индикатора одрживог развоја бања у Србији. У раду се полази од најновије поделе индикатора одрживог развоја туристичке дестинације коју је дала Европска комисија. Циь рада је рангирање водећих бања у Србији према нивоу економске одрживости туризма.У раду cy примењене VIKOR метода, за утврђивање нивоа економске одржсивости развоја туристичке дестинације, и FАNMA метода, за утврђивање тежсинских коефищијената који су неопходни за примену VIKOR методе. На основу VIKOR методе, а полазећи од економских индикатора одрживости развоја туристичке дестиначије извриено је рангирање водећих бања Србије према економској одржсиости юиховог развоја као туристичких дестинација. Резултати истраживања указују креаторима развојних политика у туризму ка којим бањама Србије треба усмерити активности у ичиьу повећања нивоа юиховог економски одрживог развоја.
\end{abstract}

Кључне речи: туристичка дестинација, развој, бање, економски показатељи, одрживост

\section{Introduction}

In Serbia, the spas have a long history of development, and spa tourism has a long and rich tradition. In addition to the long development history, it may be concluded that Serbia is one of the richest areas of mineral and thermal mineral waters in Europe. Hence, priority in the development of tourism in Serbia should be given to spas, with the inevitable emphasis on the sustainable development of spa tourism. Sustainable tourism development of spas should be based on an integrated, holistic approach. Increasing the social responsibilities of the spas in the private and public ownership can increase the level of economic and sustainable development of tourism.

In order to determine the level of sustainable development of tourism in the spas in Serbia, the paper uses a system of indicators of tourist destinations sustainable development proposed by the European Commission (European Commission, 2013, p. 21-22). This system of indicators in the field of tourism includes the following sets of indicators: Destinations Management, Economic Value, Social and Cultural Impact, and Environmental Impact. All these groups of indicators can be divided into the Core and Optional Indicators. Since the Core indicators represent a starting point for measuring the level of tourism destinations sustainability, in this paper, special attention is paid to the so-called Economic Value Core Indicators.

This paper will point out to the possibility of applying VIKOR methods to determine the level of sustainable development of spas in Serbia starting from economic indicators defined by the European Commission. Application of this method for multiple criteria 
decision making will enable ranking of spas from the standpoint of economic indicators of the tourism sustainability. At the same time, based on the identified and analysed the development levels of sustainable tourism, the measures that are necessary to implement a tourist destination and its entities will determine in order to manage the development of sustainable tourism. Another method that was used in the work, which is a prerequisite for applying VIKOR method, is FANMA for determining weight coefficients. FANMA method is chosen because it is objective and generates weights of criteria directly from the criterion value variants. It also eliminates the problem of subjectivity and incompetence. The analysis in this paper focuses on three major spas in Serbia as a well-known tourist destination: Vrnjačka Banja, Sokobanja and Niška Banja. The criteria that are taken for evaluation of the economic viability of tourism in these spas are: Number of tourist nights per month, Average length of stay of tourists (nights), Occupancy rate in accommodation average for the year, and Direct tourism employment as a percentage of total employment.

\section{Theoretical background}

The concept of sustainable development is an important factor when making decisions in different industries. According to the Brundtland report, sustainable development is a "development that meets the needs of the present generation without compromising the ability of future generations to meet their own needs" (WCED, 1987, p. 43). As the tourist industry becomes increasingly important for countries around the world, the need to develop tourism in a sustainable manner has also become a primary concern (Richards, Hall \& Hall, 2003). "In recent years, sustainable tourism has become an increasing political leitmotiv for tourist destinations (Tanguaya, Juste \& Therrien, 2013). "Sustainable tourism should: a) make optimal use of environmental resources that constitute a key element in tourism development, maintaining essential ecological processes and helping to conserve natural heritage and biodiversity; b) respect the socio-cultural authenticity of host communities, conserve their built and living cultural heritage and traditional values, and contribute to inter-cultural understanding and tolerance; c) ensure viable, long-term economic operations, providing socio-economic benefits to all stakeholders that are fairly distributed, including stable employment and incomeearning opportunities and social services to host communities, and contributing to poverty alleviation (UNEP \& UNWTO, 2005, p. 11-12). The WTO has adopted a sustainable approach as key to tourism's long term future and defined sustainable tourism as follows: "Sustainable tourism development meets the needs of present tourists and host regions while protecting and enhancing opportunities for the future. It is envisaged as leading to management of all resources in such a way that economic, social and aesthetic needs can be fulfilled while maintaining cultural integrity, essential ecological processes, biological diversity and life support systems" (WTO, 1995). The need for sustainability in tourism is nothing new. "However, combining social, environmental and economic principles in the integrative concept of sustainable development is an innovative contribution" (Torres-Delgado \& López, 2014, p. 123). Fast and tumultuous development of tourism imposed a necessity to research tourist market (Ubavić, 2015, p. 167). Successful tourist destination development heavily depends on the achieved level of competitiveness (Krstić, Jovanović \& Stanišić, 2014, p. 61).

A particular set of indicators is used in order to determine the level of sustainable development. In 1991, the World Tourism Organization (UNWTO) launched an initiative to 
develop indicators of sustainable tourism at the global level. According to the World Tourism Organization, indicators quantify or evaluate specific information, allowing that decisionmakers reduce the possibilities of unconscious making bad business decisions. The selection, monitoring, quantification, and evaluation of appropriate indicators of sustainable tourism is a very complex and demanding job, although it is simple in theory. In addition to the World Tourism Organization, European Union, OECD and other international organizations, numerous teams of experts over the past two decades have been dealing with the problems of defining and implementation of indicators of sustainable tourism (Miller \& Twining-Ward, 2006, p. 148).

Professional consultants of the European Commission, summarizing the results of research conducted in various tourist destinations, but also taking into account all the problems related to the possibility of determining carrying capacity, had drawn up a list of indicators for monitoring and determining the degree of sustainability of tourism development. In defining the indicators, they start from the need to integrate several crucial groups of factors such as: economic, ecological, social, cultural, and tourist satisfaction. The indicators that take into account these factors allow evaluation of the current state of development of tourism, and thus leads to the primary inputs to take the necessary administrative measures and activities (European Commission, 1995).

The European Commission has developed a European Tourism Indicators System for Sustainable Management at Destination Level, which is a comprehensive system, simple to use, flexible and suitable for all tourism destinations. The system is designed to be used by tourism destinations to monitor, manage, measure and enhance their sustainability performances, without the need of any specific training. This system has 27 core and 40 optional indicators, which are divided into four sections: Destinations Management, Economic Value, Social and Cultural Impact, and Environmental Impact (European Commission, 2013, p. 21-22). Destination management indicators emphasize important decision-making and communication issues that contribute to sustainable tourism management in the destination. Economic value indicators help track the contribution of tourism to economic sustainability in the destination. Social and cultural impact indicators focus on the effects of tourism on the residents and cultural heritage in the destination. Environmental impact indicators focus on those elements that are critical to the sustainability of the natural environment of the destination. Core indicators are the starting point for measuring the level of sustainability of tourism in destination (European Commission, 2013, p. 20).

A set of carefully selected indicators that are continuously monitored should reflect sustainable development of a particular destination. Ranking destination according to the level of sustainable development is possible using one of the methods for multiple criteria decision making. Multiple criteria decision making relating to the situation of deciding if there are more commonly conflicting criteria (Čupić, Tummala \& Suknović, 2001). Ranking alternative according to the large number of criteria at the same time, contributes to the reality of dealing with such situations. The best known multi-criteria decision-making methods are: ELECTRE, PROMETHEE, AHP, TOPSIS and VIKOR method.

\section{The importance of the spa tourism for improving the competitiveness of the tourism sector in Serbia}

Serbian spas occupy an important place on the tourist map. There are more than 1,000 sources of cold and hot mineral water, as well as a great wealth of natural mineral gas and medicinal mud in Serbia. In addition to spas rich in medicinal waters, and so-called air spas 
are important in Serbia, which are, due to favorable climatic conditions and geographic location, proclaimed as a health resort. Although the territory of Serbia is extremely rich in waters, although no country in Europe has such mineral resources as Serbia, only $30 \%$ of the groundwater potential is utilized. In addition, the incompleteness of the tourist offer, and significant differences in the ability to communicate geographical position, had a different effect on seasonal fluctuations of tourist traffic in some spas.

However, tourism Serbia, and within it, especially spa tourism are one of the activities that great results are expected and it is certainly a big chance that we should take advantage. From a total of 14 tourist places in which is recorded over 100,000 overnight stays in Serbia, even seven are spas, while Vrnjačka Banja is one of the three places which has over one million overnight stays, in addition to Belgrade and Zlatibor. The spas are dominated in the total structure of overnight stays in our country. Participation of spa tourism in total tourist nights in 2013 amounted to $32.5 \%$. It is even more pronounced participation of overnight stays of domestic tourists in spas in total overnight stays of domestic tourists in Serbia, $43.5 \%$ in 2013 . Spas occupy $27.8 \%$ of accommodation capacities in tourism of Serbia (Statistical Office of the Republic of Serbia, 2014).

Table 1 shows the number of tourists, total and average number of overnight stays, as well as accommodation capacity (number of beds) in the most frequented spas in Serbia in 2013.

Table 1: Number of tourists, the number of overnight stays and the accommodation capacity of the most popular spas in Serbia (2013)

\begin{tabular}{|l|c|c|c|c|c|}
\hline \multirow{2}{*}{ Spas } & \multirow{2}{*}{ Tourists } & \multirow{2}{*}{$\begin{array}{c}\text { Overnight } \\
\text { stays of } \\
\text { tourist }\end{array}$} & \multicolumn{2}{c|}{$\begin{array}{c}\text { The average number of } \\
\text { overnight stays }\end{array}$} & \multirow{2}{*}{$\begin{array}{c}\text { Accommodation } \\
\text { capacity (beds) }\end{array}$} \\
\cline { 4 - 5 } & & Domestic & Foreign & \\
\hline Vrnjačka Banja & 156240 & 594804 & 3.9 & 3.0 & 13110 \\
\hline Sokobanja & 50629 & 306506 & 6.1 & 3.4 & 6786 \\
\hline Niška Banja & 4440 & 29649 & 8.6 & 2.4 & 1228 \\
\hline Koviljača & 20644 & 171809 & 9.1 & 5.2 & 1228 \\
\hline Ribarska Banja & 7703 & 53018 & 8.9 & 2.5 & 247 \\
\hline Mladenovac & 6789 & 146439 & 9.3 & 5.6 & 437 \\
\hline Mataruška Banja & 4767 & 45450 & 10.0 & 2.5 & 930 \\
\hline Gornja trepča & 9814 & 104300 & 10.3 & 13.0 & 2620 \\
\hline $\begin{array}{l}\text { Gam zigra a sk a } \\
\text { Banja }\end{array}$ & 4389 & 59410 & 14.2 & 2.4 & 358 \\
\hline Sijarinska Banja & 5598 & 51426 & 9.4 & 5.4 & 858 \\
\hline Vranjska Banja & 4943 & 33000 & 7.1 & 2.8 & 208 \\
\hline Aranđelovac & 26050 & 66460 & 2.7 & 2.1 & 1002 \\
\hline $\begin{array}{l}\text { B o g u t o v a č k a } \\
\text { Banja }\end{array}$ & 2074 & 18133 & 8.8 & 7.9 & 388 \\
\hline Banja Vrujci & 9202 & 39513 & 4.3 & 4.0 & 861 \\
\hline
\end{tabular}

Source: Statistical Office of the Republic of Serbia, http://webrzs.stat.gov.rs/

These data and analyzes confirm the significant role of spa tourism in tourist traffic. Spa tourism has been considerably rising in Serbia. Popular spas are becoming soughtafter destinations. In recent years, in Serbia a lot of effort and money are invested for the 
reconstruction and improvement of te spas. The task for the coming period is the development of spa tourism on a sustainable basis.

\section{The methodology applied in the work and the research hypothesis}

Sustainable economic development of spas in Serbia is very important for the overall Serbian development and for the sustainable development of Serbian tourism. The aim of this study is ranking the leading spas in Serbia according to the level of economic sustainability of tourism.

In accordance with the research the following starting hypothesis is formulated:

The level of economic sustainability of tourism in Serbian spas as a tourist destination is directly proportional to tourist traffic.

Testing the hypothesis is done by applying VIKOR method. Information base of research represents the database of the Statistical Office of the Republic of Serbia.

VIKOR method (method for multiple criteria compromise ranking) was developed on the basis of the elements of the compromise programming. The method is based on the "borderline" form $\mathrm{L}_{\mathrm{p}}$ - Metrics (Opricović, 1986). Seeking a solution that is closest to the ideal is wanted. It is particularly suitable for situations where the quantitative criteria prevail.

VIKOR method has significant application in various scientific fields, but also in practice. In the literature, Chang and Hsu (2009) used VIKOR method for prioritizing landuse restraint strategies in the Tseng-Wen reservoir watershed. Sayadi, Heydari and Shahanaghi et al. (2009) used extension VIKOR method for the solution of the decision making problem with interval numbers. Liou, Tsai, Lin and Tzeng (2011) used a modified VIKOR method for improving the domestic airline service quality. Huang, Liou and Tzeng (2009) apply the VIKOR method of MCDM to evaluate and rank their performances for determining the alternatives of night-market system. Arzhang and Hamidi (2014) evaluated the factors that affect on the financing of tourism industry in Iran. ANP and extended VIKOR approaches have been presented under the fuzzy environment to select the most suitable place for a cruise port in Istanbul (Demirel \& Yucenur, 2011). Lui, Tzeng and Lee (2012), in their research demonstrated a holistic approach, a hybrid MCMD models (DANP and VIKOR method) for evaluating complex national tourism policies. Tsai, Chou and Lai (2010) use VIKOR method to rank Taiwanese national park websites. Overall, the results show that each national park website must be improved in order to become a high quality website. Based on the above, we can conclude that VIKOR method has significant application in tourism.

Multiple criteria decision refers to decision-making situations in which a greater number of conflicting criteria are usually present. In order to make good decisions, you need to specify an alternative definition of corresponding criteria. It is also necessary to define the weights of each criterion, and the importance of each criterion in relation to the other. Weighted coefficients represent the numbers that can be calculated using objective and subjective methods (FANMI, CRITIC, the method of weighted least squares, method of entropy, etc.).

The paper will apply an objective method for determining the values of weighted coefficients or FANMA method. This method is proposed by Fan (1996) in his dissertation 
(Fan, 1996). Short description of the method is given by Ma and colleagues (Ma, Fan \& Huang, 1999). Starting from the surnames of these authors, Srđević explained in detail the method called "FANMA method" in the case of selection variant irrigation technologies (Srđević, 2005).

\section{Results and Discussion}

\section{Determination of criteria in order to form the initial decision matrix according to VIKOR method}

The paper pays special attention to Economic Value Core Indicators, which determines the level of the economic viability of the destination. This group of indicators includes the following indicators: Number of tourist nights per month, Daily spending per tourist (accommodation, food and drinks, other services), Average length of stay of tourists (nights), Occupancy rate in commercial accommodation per month and average for the year, Direct tourism employment as percentage of total employment, Percentage of tourism enterprises inspected for fire safety in the last year and Percentage of tourism enterprises actively taking steps to source local, sustainable, and fair trade goods and services (European Commission, 2013 , p. 20). Based on the available data, the economic indicators of sustainable tourism development are calculated in Table 2 on the basis of which we will make ranking the leading spas in Serbia.

Table 2: Economic Value Core Indicators

\begin{tabular}{|l|c|c|c|c|}
\hline \multicolumn{1}{|c|}{ Spas } & $\begin{array}{c}\text { Number of } \\
\text { tourists per } \\
\text { night }\end{array}$ & $\begin{array}{c}\text { Average length } \\
\text { of stay of tourists }\end{array}$ & $\begin{array}{c}\text { Degree of } \\
\text { capacity } \\
\text { utilization }\end{array}$ & $\begin{array}{c}\text { Employees } \\
\text { in tourism in } \\
\text { relation to the } \\
\text { total number } \\
(\%)\end{array}$ \\
\hline Vrnjačka Banja & 50974.9 & 3.85 & 12.78 & 5.3 \\
\hline Sokobanja & 25542.2 & 6.05 & 12.37 & 5.6 \\
\hline Niška Banja & 2470.8 & 6.68 & 6.61 & 0.3 \\
\hline
\end{tabular}

Source: Author's calculations

According to the Number of tourists per night, Vrnjacka Banja has the advantage among the three observed spas. Also, Vrnjacka Banja had the highest level of capacity utilization. The longest Average length of stay of tourists is recorded in Niška Banja, while Sokobanja has the highest percentage of people working in tourism in relation to the total number of employees. Indicators of the economic sustainability of tourism for leading spas shown in Table 2 represent the initial decision matrix. 


\section{Ranking spas as tourist destinations based on indicators of economic sustainability of tourism according to VIKOR method}

Starting from $\mathrm{d}_{\mathrm{ij}}$ and weight criteria calculated using the FANMI method we calculated $\mathrm{S}$ and $\mathrm{R}$ (Table 3).

Table 3: Calculated values of $w_{i j} * d_{i j}$, S and $R$

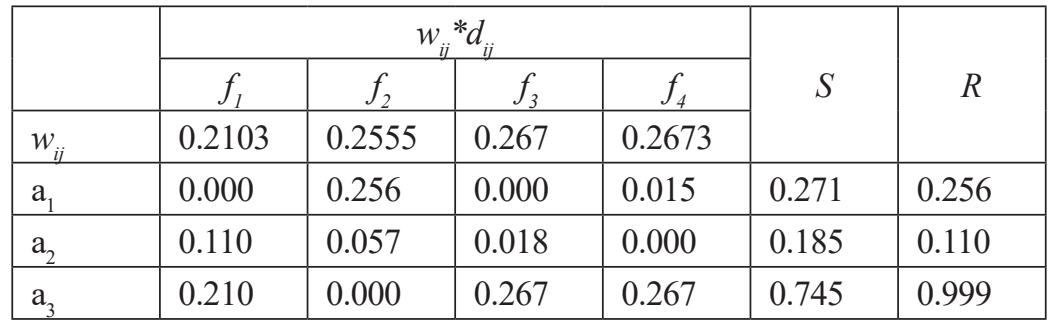

Source: Author's calculations

According to the obtained values QS, QR and Qi for each spa, three independent rankings can be formed. According to all criteria, QS, QR and Qi $(v=0.5)$, alternative $\mathrm{A}_{2}$ (Sokobanja) is the best. Alternative $\mathrm{A}_{2}$ satisfies the condition $\mathrm{U} 1$ because

$$
\begin{gathered}
\mathrm{Q}_{2}-\mathrm{Q}_{4}=0,540-0,001=0,539 \\
\mathrm{DQ}=\min (0.25 ; 1 /(3-1))=0,25 \\
\mathrm{Q}_{2}-\mathrm{Q}_{4}>\mathrm{DQ}
\end{gathered}
$$

It can be said that alternative $\mathrm{A}_{2}$ has a sufficient advantage with respect to the second alternative $A_{1}$, i.e. Vrnjačka banja. At the same time, alternative $A_{2}$ meets the requirement of $\mathrm{U} 2$ because it is on the first place in all rankings. Since it meets two conditions, we can conclude that the Sokobanja achieved a higher level of economic sustainability of tourism development in relation to the Vrnjačka banja. Ranking is made in Table 4.

Table 4: Ranking list based on $Q S, Q R$ and $Q_{i}(v=0.5)$

\begin{tabular}{|l|l|l|l|l|l|}
\hline & $Q S$ & $Q R$ & $Q_{i}(v=0.5)$ & $Q_{i}(v=0.25)$ & $Q_{i}(v=0.75)$ \\
\hline $\mathrm{a}_{1}$ & 0.153 & 0.927 & 0.540 & 0.733 & 0.346 \\
\hline $\mathrm{a}_{2}$ & 0.000 & 0.002 & 0.001 & 0.001 & 0.000 \\
\hline $\mathrm{a}_{3}$ & 0.999 & 1.000 & 1.000 & 1.000 & 0.999 \\
\hline
\end{tabular}

Source: Author's calculations

We perform an analysis of alternatives $\mathrm{A}_{1}$, the second on the ranking list $Q_{i}(v=0,5)$

Testing condition $\mathrm{U}_{1}$

$\mathrm{Q}_{3}-\mathrm{Q}_{1}=1,000-0,540>0,25$

The first condition was met, because the second alternative $\mathrm{A}_{1}$ has "sufficient advantage" in relation to the third-ranking alternative $\mathrm{A}_{3}$. 
U2 condition is fulfilled because the alternative has enough stable the second place according to all criteria. Thus, the highest level of economic sustainability of tourism has Sokobanja. Vrnjacka Banja is in second place, and Niska Banja is on the third place. Based on this we can conclude that the defined hypothesis is rejected. The Vrnjacka Banja is a resort that has the highest tourist traffic between the spas in Serbia. However, Vrnjacka Banja is not spa which achieved the highest level of economic sustainability of tourism.

\section{Conclusion}

Sustainable tourism development is imperative that arises in modern conditions. Given the role and significance of spa tourism in the tourist offer of Serbia, the sustainable development of spa tourism should be imperative for makers of development policies in Serbia. In order to manage sustainable tourism development, it is necessary to continually monitor and analyze of sustainability indicators.

The paper presents one of the possible ways of analysis of indicators. It can be concluded that the multi-criteria analysis can be successfully applied for the ranking of spas according to the level of economic sustainability of tourism. This has been demonstrated in the example that is solved by the methods VIKOR. This method enables the implementation of a holistic approach and allows that spas to be ranked according to the level of economic sustainability of tourism starting from a larger number of indicators. It is necessary to emphasize that it is possible to change the criteria (number and type of indicators) and their weight, depending on the tourist destinations that are observed. Also, it is possible to apply other methods of multicriteria analysis for the ranking of spas and other tourist destinations according to the level of sustainable development of tourism.

According to the results of the research in this paper, Sokobanja has made the highest level of economic sustainable development in tourism, while the lowest level is achieved in Niška Banja. In order to increase the level of sustainable tourism in Niška Banja, it is necessary to apply measures that will contribute to the economic sustainability of tourism. Achievement of this goal requires better cooperation between the public and private sectors that would contribute to increasing the quantity and quality of the tourist offer of this destination. It is also essential that policy makers of tourism development find a balance between the opportunities for development of Vrnjačka banja, as spa with the highest potential in Serbia, and level of economic sustainability of tourism.

\section{References}

Arzhang, P., Hamidi, N. (2014). Financing of tourism industry - A hybrid approach DELPHI-ANP-VIKOR. Arabian Journal of Business and Management Review, 3 (8), 17-26.

Chang, C.L., Hsu, C.H. (2009). Multi-Criteria Analysis Via the VIKOR Method for Prioritizing Land-Use Restraint Strategies in the Tseng-Wen Reservoir Watershed. Journal of Environmental Management, 90 (11), 3226-3230. 
Čupić, M., Tummala, R., \& Suknović, M. (2001). Odlučivanje: formalni pristup. Fakultet organizacionih nauka. Beograd.

Demirel, N., Yucenur, N. (2011). The cruise port place selection problem with extended VIKOR and ANP methodologies under Fuzzy environment. Proceedings of the World Congress on Engineering 2011 Vol II WCE 2011, July 6-8, 2011, London, U.K.

European Commission, http://ec.europa.eu/enterprise/sectors/tourism/sustainabletourism/indicators/index_en.htm (15.1.2015)

European Commission. (1995). Tourism and the Environment in Europe. Brussels.

European Commission. 2013. The European Tourism Indicator System - Toolkit for Sustainable Destinations, February 2013.

Fan, Z. P. (1996). Complicated multiple attribute decision making: theory and applications. $\mathrm{Ph} . \mathrm{D}$. Dissertation. Northeastern University. Shenyang, PRC.

Huang, S., Liou, Y., \& Tzeng, G. (2009). Development strategies for improving the services of tourist night markets through hybrid MCDM technique. International Journal of Information Systems for Logistics and Management, 5 (1), 53-68.

Krstić, B., Jovanović, S., \& Stanišić, T. (2014). Central and East European countries' tourism competitiveness as a factor of their national competitiveness level. Journal of tourism - studies and research in tourism, 18, 61-68.

Liou, J.J., Tsai, C., Lin, R., \& Tzeng, G. (2011). A modified VIKOR multiple-criteria decision method for improving domestic airline service quality. Journal of Air Transport Management, 17 (2), 57-61.

Lui, C., Tzeng, G., \& Lee, M. (2012). Improving tourism policy implementation - The use of hybrid MCDM models. Tourism Management, 33 (2), 413-426.

Ma J., Fan Z. P., \& Huang L. H. (1999). A subjective and objective integrated approach to determine attribute weights. European Journal of Operations Research, 112 (2), 397-404.

Miller, G., Twining-Ward L. (2006). Monitoring for a Sustainable Tourism Transition: The Challenge of Developing and Using Indicators. CABI Publishing.

Opricović, S. (1986). Višekriterijumska optimizacija. Naučna knjiga. Beograd.

Opricović, S., Tzeng, G. (2007). Extended VIKOR method in comparison with outranking methods. European Journal of Operational Research, 178 (2), 514-529.

Republički zavod za statistiku. (2014). Statistički godišnjak Republike Srbije 2013, http:// webrzs.stat.gov.rs/ (15.5.2015)

Richards, G., Hall, D., \& Hall, D. R. (Eds.). (2003). Tourism and sustainable community development. Psychology Press, Vol. 7.

Sayadi, M.K., Heydari, M. \& Shahanaghi, K. (2009). Extension of VIKOR Method for Decision Making Problem with Interval Numbers". Applied Mathematical Modelling, 33 (2), 2257-2262.

Srđević, B. (2005). Nepristrasna ocena značaja krtierijuma u višekriterijumskoj optimizaciji. Vodoprivreda, 37 (1-3), 53-58. 
Tanguaya, G.A., Juste, R., \& Therrien, M.C. (2013). Sustainable tourism indicators: selection criteria for policy implementation and scientific recognition. Journal of Sustainable Tourism, 21 (6), 862-879.

Torres-Delgado, A., Francesc López P. (2014). Measuring sustainable tourism at the municipal level. Annals of Tourism Research, Vol. 49, 122-137.

Tsai, W., Chou, W., \& Lai, C. (2010) An effective evaluation model and improvement analysis for national park websites: A case study of Taiwan, Tourism Management, 31 (6): 936-952.

Ubavić, P. (2015). Informational resources management in tourism. Ekonomika, LXI (1): $161-172$.

UNEP and UNWTO. (2005). Making Tourism More Sustainable - A Guide for Policy Makers.

WCED - World Commission on Environment and Development. (1987). Our Common Future, Oxford University Press. Oxford.

WTO. (1995). What Tourism Managers Need to Know. International Working Group on Indicators of Sustainable Tourism and Consulting and Audit Canada. Madrid. 